Article

\title{
Impact of VOCs and NOx on Ozone Formation in Moscow
}

\author{
Elena Berezina *, Konstantin Moiseenko, Andrei Skorokhod, Natalia V. Pankratova, Igor Belikov, \\ Valery Belousov and Nikolai F. Elansky
}

A.M. Obukhov Institute of Atmospheric Physics, Russian Academy of Sciences, 119017 Moscow, Russia; konst.dvina@gmail.com (K.M.); skorokhod@ifaran.ru (A.S.); n_pankratova@list.ru (N.V.P.); uawgr@mail.ru (I.B.); binomod@gmail.com (V.B.); n.f.elansky@mail.ru (N.F.E.)

* Correspondence: e_berezina_83@mail.ru

Received: 7 October 2020; Accepted: 19 November 2020; Published: 23 November 2020

\begin{abstract}
Volatile organic compounds (VOCs), ozone $\left(\mathrm{O}_{3}\right)$, nitrogen oxides (NOx), carbon monoxide (CO), meteorological parameters, and total non-methane hydrocarbons (NMHC) were analyzed from simultaneous measurements at the MSU-IAP (Moscow State University-Institute of Atmospheric Physics) observational site in Moscow from 2011-2013. Seasonal and diurnal variability of the compounds was studied. The highest $\mathrm{O}_{3}$ concentration in Moscow was observed in the summer daytime periods in anticyclonic meteorological conditions under poor ventilation of the atmospheric boundary layer and high temperatures (up to $105 \mathrm{ppbv}$ or $210 \mu \mathrm{g} / \mathrm{m}^{3}$ ). In contrast, $\mathrm{NOx}, \mathrm{CO}$, and benzene decreased from 8 a.m. to 5-6 p.m. local time (LT). The high positive correlation of daytime $\mathrm{O}_{3}$ with secondary VOCs affirmed an important role of photochemical $\mathrm{O}_{3}$ production in Moscow during the summers of 2011-2013. The summertime average concentrations of the biogenic VOCs isoprene and monoterpenes were observed to be $0.73 \mathrm{ppbv}$ and $0.53 \mathrm{ppbv}$, respectively. The principal source of anthropogenic VOCs in Moscow was established to be local vehicle emissions. Yet, only about $5 \%$ of the observed isoprene was safely attributed to anthropogenic sources, suggesting significant contribution of biogenic sources into the total levels of ozone precursors. The non-linear $\mathrm{O}_{3}-\mathrm{NOx}$ dependence shows a decrease in ground-level $\mathrm{O}_{3}$ with an increase in $\mathrm{NOx}$ during the summers of 2011-2013, which is typical for the VOC-sensitive photochemical regime of $\mathrm{O}_{3}$ formation. Nevertheless, during the elevated ozone episodes in July 2011, the photochemical regime of ozone production was either transitional or NOx-sensitive. Contribution of various anthropogenic and biogenic VOCs into the measured ozone values was evaluated. The ozone-forming potential (OFP) of total VOCs was $31-67 \mu \mathrm{g} / \mathrm{m}^{3}$ on average and exceeded $100 \mu \mathrm{g} / \mathrm{m}^{3}$ in the top $10 \%$ of high ozone events, reaching $136 \mu \mathrm{g} / \mathrm{m}^{3}$. Acetaldehyde, 1.3-butadiene, and isoprene have the highest ozone production potential in Moscow compared to that of other measured VOCs.
\end{abstract}

Keywords: air pollution; ozone production; volatile organic compounds; atmospheric photochemistry

\section{Introduction}

Ozone $\left(\mathrm{O}_{3}\right)$ is one of the most important secondary pollutants of the atmosphere for a variety of environmental conditions ranging from heavily polluted urban atmospheres to remote areas subjected to the impact of regional (biomass burning) and distal sources of ozone precursors through long-range transport [1,2]. In cities, $\mathrm{O}_{3}$ is mainly formed from complex photochemical interactions of volatile organic compounds (VOCs) and nitrogen oxides (NOx) [3-6]. VOCs help in oxidizing primary NO released from various sources to form $\mathrm{NO}_{2}$ and in retaining the existing ozone by competing with ozone to react with NO [6]. Reductions in VOCs emissions from local and/or upwind sources will decrease ambient ozone formation (and ground-level ozone concentrations) in VOC-sensitive areas 
but increase ozone production in NOx-sensitive areas. On the other hand, controls of NOx emissions will decrease ozone formation in areas with the NOx-sensitive regime but increase ozone formation in VOC-sensitive areas [6-11].

Downwind from climatically important atmospheric pollution sources, ozone production is largely NOx-sensitive at a regional scale, though urban areas with high NOx emissions are frequently VOC-sensitive $[10,12]$. However, some observation-based studies $[4,6,10,11,13]$ have shown that $\mathrm{O}_{3}$ production in an urban environment can also be NOx-sensitive or at least have a mixed (transitional) regime $[5,6,8,12-18]$. The latter may indicate that ozone production in cities is sensitive to specific meteorological conditions affecting a VOC/NOx ratio through a vertical mixing in the planetary boundary layer for a given strength of ozone precursor emission sources. Hence, a closer study of high ozone events in large cities is important for choosing an effective ozone control strategy through reduction of VOCs and/or NOx emissions [10,12].

Ozone concentrations higher than $50 \mathrm{ppbv}$ have a detrimental effect on plants, and levels higher than $100 \mathrm{ppbv}$ cause irreversible changes in the human respiratory system [19]. High air temperature and low wind speeds create the most favorable conditions for ozone photochemical production in Moscow, as in other world megacities, with the daytime ozone levels frequently exceeding its maximum allowable concentration (MAC $=80 \mathrm{ppbv}$ or $160 \mu \mathrm{g} / \mathrm{m}^{3}$ ). Ozone concentrations exceeding the MAC were recorded in Moscow under strong anticyclonic conditions [20-26].

Despite a significant reduction of industrial plants in Moscow over recent decades, the problem of air pollution continues to be urgent due to the rapid and steady growth of the city's car fleet and the expansion of the motorway area. Hence, understanding the relationship between ozone production and its precursors as well as their impact on ozone generation is important for development of an effective ozone control strategy. We studied diurnal and seasonal variability of ozone and its precursors in the surface air in Moscow; determined the regime of ozone generation; and quantified the contribution of anthropogenic and biogenic VOCs to $\mathrm{O}_{3}$ generation in polluted urban air.

\section{Experiments}

Ground level concentrations of various species including VOCs (acetaldehyde, ethanol, 1.3-butadiene, acetone, acetic acid, isoprene, MVK + MACR (isoprene products), benzene, 2-methyl-3buten-2-ol (MBO), toluene, phenol, styrene, C8-aromatics, C9-aromatics, and monoterpenes) and meteorological parameters (air temperature, atmospheric pressure and humidity, solar radiation, wind speed and direction, cloud height, and rainfall amount) were simultaneously measured (Table 1) at the joint ecological station of the Obukhov Institute of Atmospheric Physics, Russian Academy of Sciences, and the Geographic Faculty of Moscow State University (MSU-IAP) [20]. The site is located in the southwestern part of Moscow (about $8 \mathrm{~km}$ away from the city center) in the green area of the Botanical Gardens of Moscow State University. The nearest roads with intense traffic are about 300-450 m away from the site.

Table 1. The compounds measured at the Institute of Atmospheric Physics, Russian Academy of Sciences, and the Geographic Faculty of Moscow State University (MSU-IAP) site. NOx: nitrogen oxide; $\mathrm{O}_{3}$ : ozone; $\mathrm{CO}$ : carbon monoxide; NMHC: non-methane hydrocarbons; VOCs: volatile organic compounds.

\begin{tabular}{llll}
\hline Compound & Instrument & Response Time, $\mathbf{s}$ & Range Limits \\
\hline $\mathrm{NOx}, \mathrm{ppbv}$ & TE42C-TL (Thermo Inc., USA) & 60 & $0.05-200$ \\
$\mathrm{O}_{3}, \mathrm{ppbv}$ & 1008AH (Dasibi Inc., USA) & 60 & $1-1000$ \\
$\mathrm{CO}, \mathrm{ppmv}$ & TE48S (Thermo Inc., USA) & 60 & $0.05-10$ \\
$\mathrm{NMHC}, \mu / \mathrm{m}^{3}$ & APHA-360 (Horiba Inc., Japan) & 60 & $0.1-100$ \\
$\mathrm{VOCs}, \mathrm{ppbv}$ & Compact PTR-MS (Ionicon Analytic $\mathrm{GmbH}$, Austria) & $0.5 /$ each comp. & $0.05-1000$ \\
\hline
\end{tabular}

The measurements at the MSU-IAP site corresponded to the State Standards [27] and satisiued the international requirements for measuring systems operating at the Global Atmospheric Watch network 
of the World Meteorological Organization (GAW WMO) (see $[28,29]$ for the complete description of the measurement devices). One-hour averages of the measured compounds are used in the subsequent discussion.

\section{Results}

\subsection{Diurnal and Seasonal Variability of Inorganic and Organic Species}

According to Figure 1a, the highest daytime ozone levels in Moscow were observed from April to August, following closely the annual cycle of the total intensity of solar UV radiation measured at the MSU-IAP site [30-32]. The observed abrupt increase of ozone levels in early spring, peaking in April, is a general feature of ozone climatology over the continent as evidenced from a variety of ozone measurements in both polluted and background environments [33,34]. It has been suggested previously that the accumulation of ozone precursors during the cold season at northern latitudes provides a great potential for intense production of ozone under rapid increases of solar UV radiation in late winter and into early spring (see more discussion in [20,34,35]). It is likely that the observed springtime ozone maximum at MSU-IAP has two primary contributions, which are the large-scale tropospheric chemistry and local ozone photochemical production in the polluted boundary layer under sufficient abundance of odd nitrogen species. Another distinct feature of the MSU-IAP ozone seasonal cycle is a prolonged spring-summer maximum $[28,35,36]$, which undoubtedly reflects the primary contribution of large local sources of ozone precursors in the photochemically active period (April-September) [34] and not the downward ozone flux from the stratosphere and continental-scale transport from other potentially important areas of net photochemical production of ozone in the western part of North Eurasia. Over the whole observation period, the highest ozone levels were observed in July 2011, when daytime $\mathrm{O}_{3}$ mixing ratios exceeded the short-time MAC ( $80 \mathrm{ppb}$ or $160 \mu \mathrm{g} / \mathrm{m}^{3}$ ). These episodes are described in detail below.
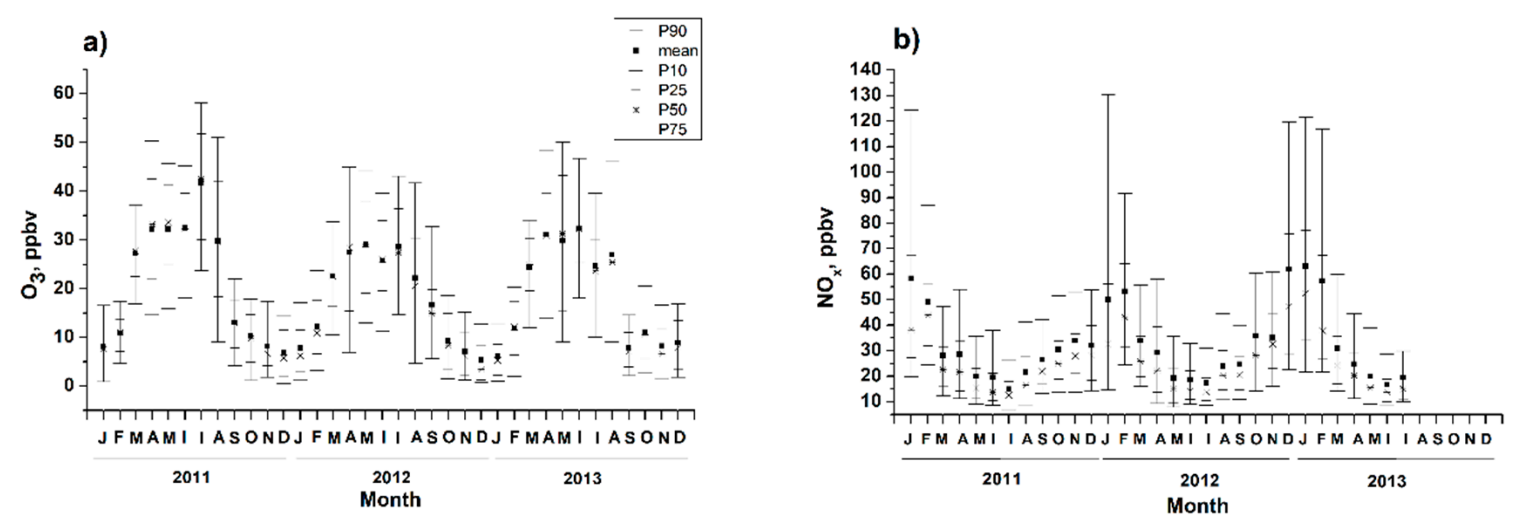

Figure 1. Seasonal variation of daytime $\mathrm{O}_{3}(\mathbf{a})$ and $\mathrm{NOx}(\mathbf{b})$ concentrations in Moscow from 2011 to 2013 (MSU-IAP data).

Seasonal daytime NOx variation is opposite to that of $\mathrm{O}_{3}$ (Figure $1 \mathrm{~b}$ ) with the highest values being observed in winter (up to $130 \mathrm{ppbv}$ ). In summer, NOx levels usually did not exceed $30 \mathrm{ppbv}$. Evidently, the observed four-fold increase in wintertime NOx levels with respect to the summer values is a local manifestation of seasonal variations in vertical mixing intensity and associated atmospheric residence times of pollutants in the lower troposphere over the continent.

Since the origin of the observed enhanced levels of ozone in Moscow during the summer months is photochemical generation, we focus below on the summertime period of the observations to explore some basic features of the urban ozone photochemistry.

Meteorological observations at the MSU-IAP site during the summers of 2011-2013 (Figure 2) show favorable conditions for accumulation of ozone precursors in the surface air and active photochemistry during a substantial part of the summer months. In the observed period, daytime air temperature 
often reached $25-30{ }^{\circ} \mathrm{C}$. Wind speeds were $\leq 2 \mathrm{~m} / \mathrm{s}$ on average and exceeded $3 \mathrm{~m} / \mathrm{s}$ only in $5 \%$ of the whole observation time, thus evidencing generally stagnant meteorological conditions. The prevailing wind directions were from $\mathrm{W}$ and $\mathrm{NW}$ to $\mathrm{N}$, which correspond to the transport of relatively clean air, subjected to a limited impact of regional pollution sources.

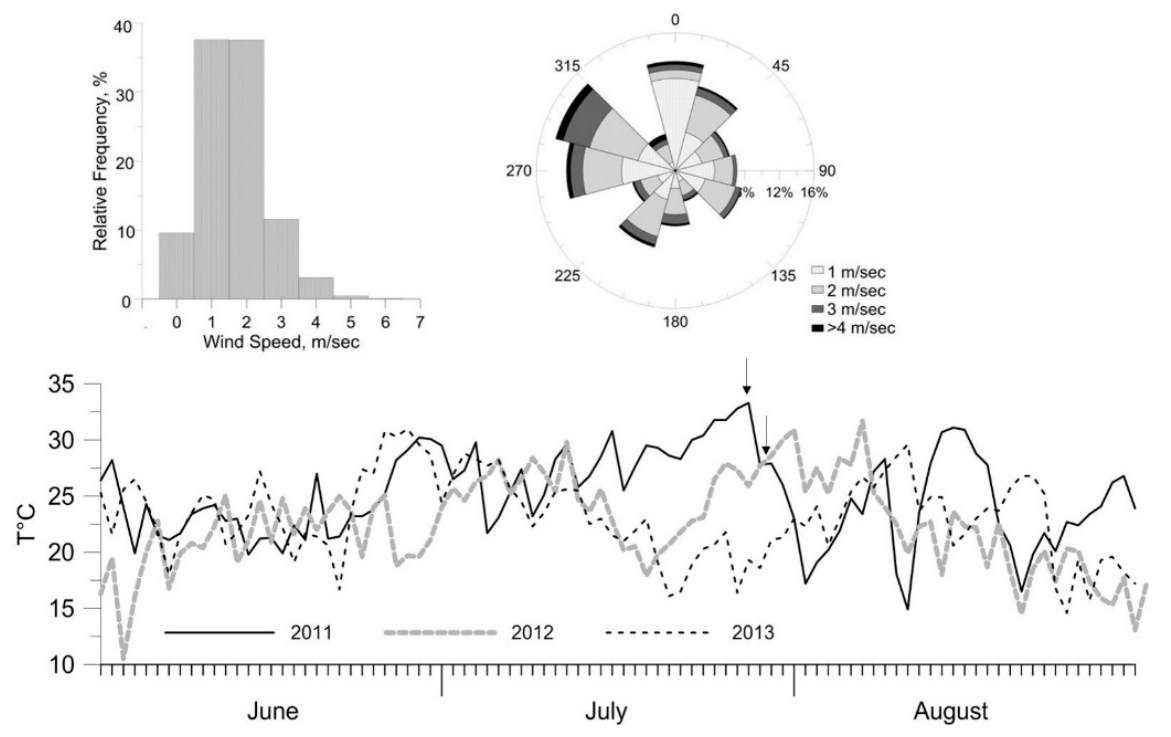

Figure 2. Wind speed, wind rose and maximum daytime air temperature from 3-h MSU-IAP observations during the summers of 2011-2013. Down arrows are elevated ozone ( $>80$ ppbv) episodes.

According to Figure $3, \mathrm{O}_{3}$ mixing ratio increases monotonically from early morning, reaching its maximum value of $34 \mathrm{ppbv}$ (sample mean) at $\sim 4$ p.m. LT The diurnal variations of NOx, CO, and benzene, the latter being an important ozone precursor with anthropogenic origin, are opposite to that of $\mathrm{O}_{3}$ and characterized by a stable decrease from their morning peak values at 8 a.m. to late afternoon minimums at $\sim 3-4$ p.m. LT. Thus, the observed diurnal variation of the secondary pollutants was strongly and negatively correlated in the day time hours with the depth of the convective mixing layer, and the associated changes with vertical mixing intensity, over Moscow, which peaks at 1-3 p.m. LT, following a daily cycle of radiation and heat balance [37]. Additionally, chemical distraction of the primary emitted VOCs, with benzene as an example, may contribute to their late afternoon decrease accompanied by significant accumulation of ozone and other secondary pollutants (Figure 4). According to Figure 4, the maximum $\mathrm{O}_{3}$ production rate is observed during the late morning hours (10-12 a.m. LT), which also coincides with diurnal peaks of the most abundant secondary VOCs (acetaldehyde, acetone, and acetic acid). The origin of the observed late morning maximum of the above species can be attributed to both photochemical oxidation of primary emitted VOCs after sunrise and entrainment of partially oxidized products from the upper layers under development of the convective boundary layer. The latter may be especially efficient for ozone accumulation in prolonged stagnation conditions leading to overnight retention of secondary organics above a nocturnal inversion layer [38]. All compounds discussed except for $\mathrm{O}_{3}$ are not normally distributed (see Figure $\mathrm{S} 1$ in the Supplementary Materials). Thus, we calculated the nonparametric Spearman's correlation coefficients $\left(\mathrm{R}_{\mathrm{s}}\right)$ to measure the strength of association between maximal afternoon $\mathrm{O}_{3}(3-5$ p.m. LT) and maximal morning (10-12 a.m. LT) mixing ratios of some secondary VOCs during the summer months from 2011-2013. High correlations were found between acetaldehyde, ethanol, acetone, and acetic acid $\left(R_{S}=0.55-0.91\right)$ as well as between the above species and the products of isoprene oxidation, MVK and MACR $\left(\mathrm{R}_{\mathrm{s}}=0.67-0.81\right)$ (Table 2$)$. The positive correlation of daytime $\mathrm{O}_{3}\left(\mathrm{R}_{\mathrm{s}}=0.45-0.52\right)$ with secondary VOCs affirms an important role of photochemical $\mathrm{O}_{3}$ production in Moscow during the summers of 2011-2013. 

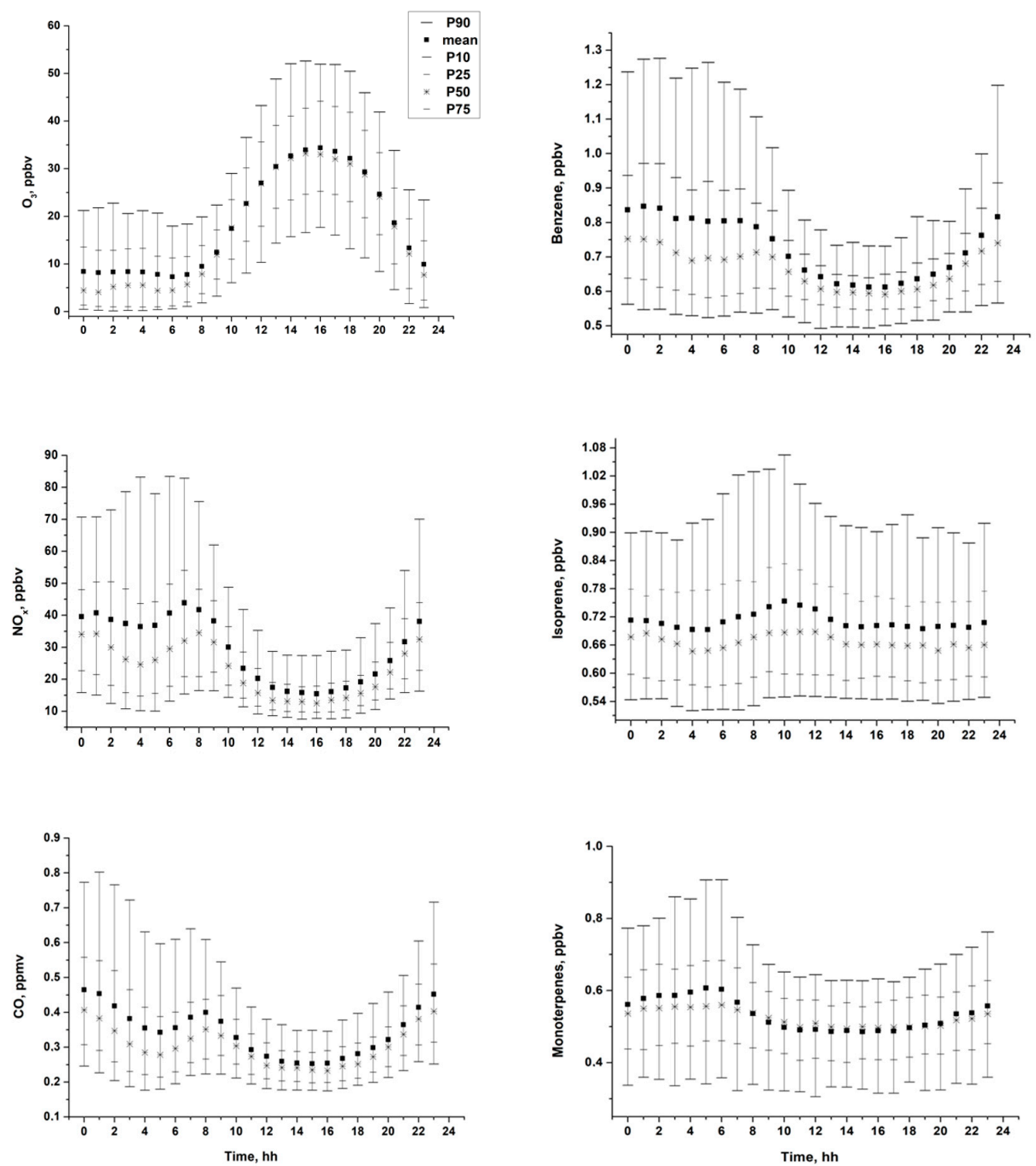

Figure 3. Diurnal variations of $\mathrm{O}_{3}$ and its precursors at the MSU-IAP site during the summers of 2011-2013.

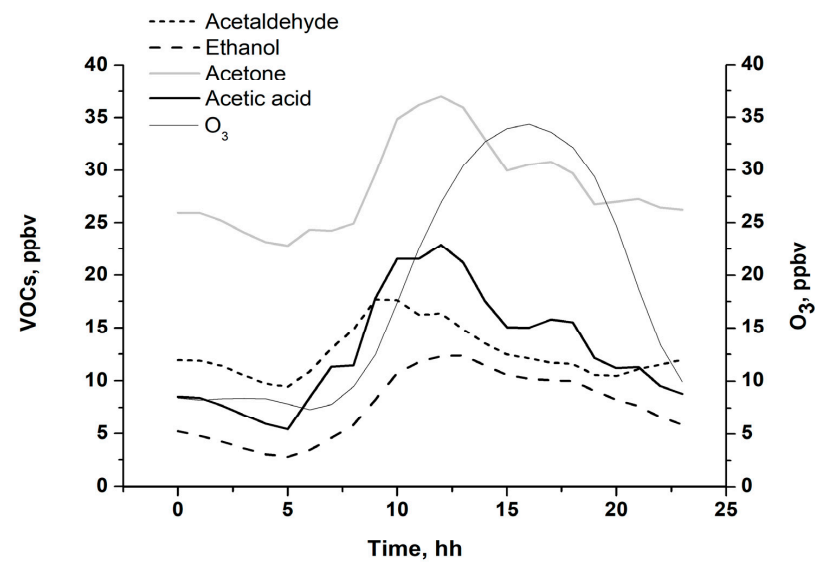

Figure 4. Mean diurnal variations of $\mathrm{O}_{3}$ and secondary VOCs at the MSU-IAP site during the summers of 2011-2013. 
Table 2. Daytime summer nonparametric Spearman's correlation coefficients $\left(\mathrm{R}_{S}\right)$ of $\mathrm{O}_{3}$ and its precursors from 1-h data. Significant at the 0.05 level.

\begin{tabular}{lcccccccc}
\hline & Acetaldeh. & Acetone & Acet.acid & Ethanol & MVK + MACR & O $_{3}$ & CO & NOx \\
\hline Acetaldeh. & 1.00 & 0.91 & 0.62 & 0.55 & 0.81 & 0.47 & 0.00 & 0.00 \\
Acetone & 0.91 & 1.00 & 0.58 & 0.45 & 0.82 & 0.45 & 0.11 & 0.00 \\
Acet.acid & 0.62 & 0.58 & 1.00 & 0.82 & 0.75 & 0.60 & -0.09 & 0.00 \\
Ethanol & 0.55 & 0.45 & 0.82 & 1.00 & 0.67 & 0.52 & -0.16 & -0.09 \\
MVK + MACR & 0.78 & 0.82 & 0.75 & 0.67 & 1.00 & 0.49 & 0.00 & 0.00 \\
$\mathrm{O}_{3}$ & 0.47 & 0.45 & 0.60 & 0.52 & 0.49 & 1.00 & -0.39 & -0.49 \\
$\mathrm{CO}$ & 0.00 & 0.11 & -0.09 & -0.16 & 0.00 & -0.39 & 1.00 & 0.82 \\
NOx & 0.00 & 0.00 & 0.00 & -0.09 & 0.00 & -0.49 & 0.82 & 1 \\
\hline
\end{tabular}

According to the MSU-IAP observations, the toluene to benzene ratio $(\mathrm{T} / \mathrm{B})$ was mainly in the range of $1-2($ mean $=1.39 ; \mathrm{P} 75=1.50 ; \mathrm{P} 90=1.89)($ Figure 5$)$. This ratio is known to be a safe indicator of vehicle pollution as well as proximity of the sampled air to the associated pollution sources [39-43]. A T/B ratio approaching 1 indicates traffic-originated emission sources, and the value increases with the closeness of the pollution source [44]. It suggests that the dominated anthropogenic VOCs source in the region of the MSU-IAP site during the summers of 2011-2013 was local vehicle emissions.

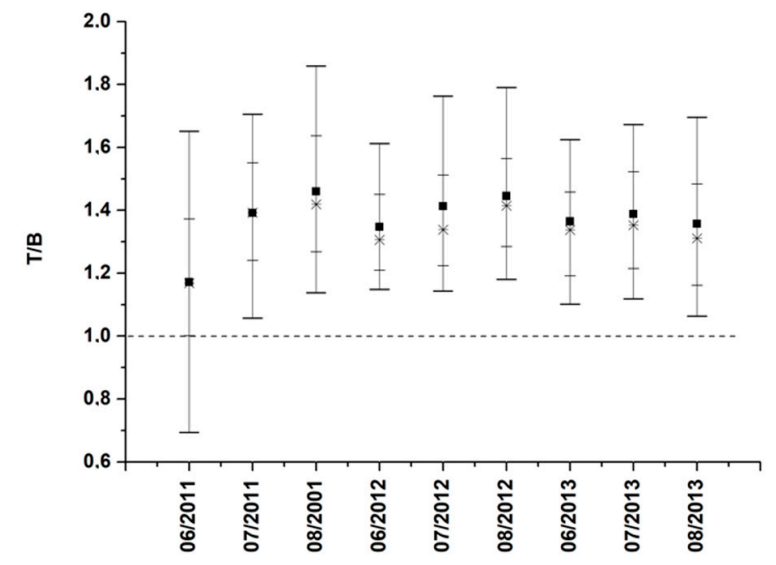

Figure 5. Toluene to benzene ratio (T/B) ratio in Moscow from daytime summer values.

The diurnal cycles of biogenic VOCs, isoprene, and monoterpenes were generally weak (Figure 3), which can be explained by the direction of the prevailing winds (Figure 2) blowing mainly from areas with highly limited vegetation. Isoprene levels are the highest during the morning hours (07:00-10:00 a.m.) whereas monoterpenes increase during evening and nighttime hours owing to their emissions at these hours and accumulation in the stable atmosphere.

Since motor vehicle emissions dominate over other pollution sources in urban environments, VOCs primarily produced by motor vehicles (benzene, 1.3-butadiene etc.) are commonly used as suitable exhaust tracers. This allows for quantifying the traffic contributions to ambient isoprene and then separating biogenic isoprene from traffic emissions [45-47]. The nighttime isoprene/anthropogenic VOC ratio in a vehicle-polluted atmosphere is supposed to characterize vehicle exhaust $[46,48]$. We then used benzene concentration to estimate the traffic contribution to isoprene at the MSU-IAP site. Since biogenic isoprene emissions are strongly dependent on air temperature and the amount of local vegetation, nighttime winter isoprene concentrations are supposed to be of anthropogenic origin. Consequently, the monthly mean diurnal isoprene/benzene ratio was lowest during the cold season and reached its maximum during the summer months (mean $=0.94)$, thus following a seasonal cycle of biogenic isoprene emissions (Figure 6). Yet, the observed high positive nonparametric Spearman's correlation between isoprene and benzene on summer days $\left(R_{s}=0.69\right)$ clearly indicates significant contribution of the anthropogenic signal in isoprene data during the warm season as well. A 
somewhat better correlation is observed for nighttime winter values $\left(R_{S}=0.75\right)$. The nighttime winter isoprene/benzene ratio in the observed site was calculated to be 0.7 on average (see scatter diagram on Figure 6). It was about $5 \%$ of the summer daytime isoprene/benzene ratios. Thus, we suppose that about $5 \%$ of the daytime summer isoprene in Moscow had an anthropogenic origin, presumably from vehicle exhaust.

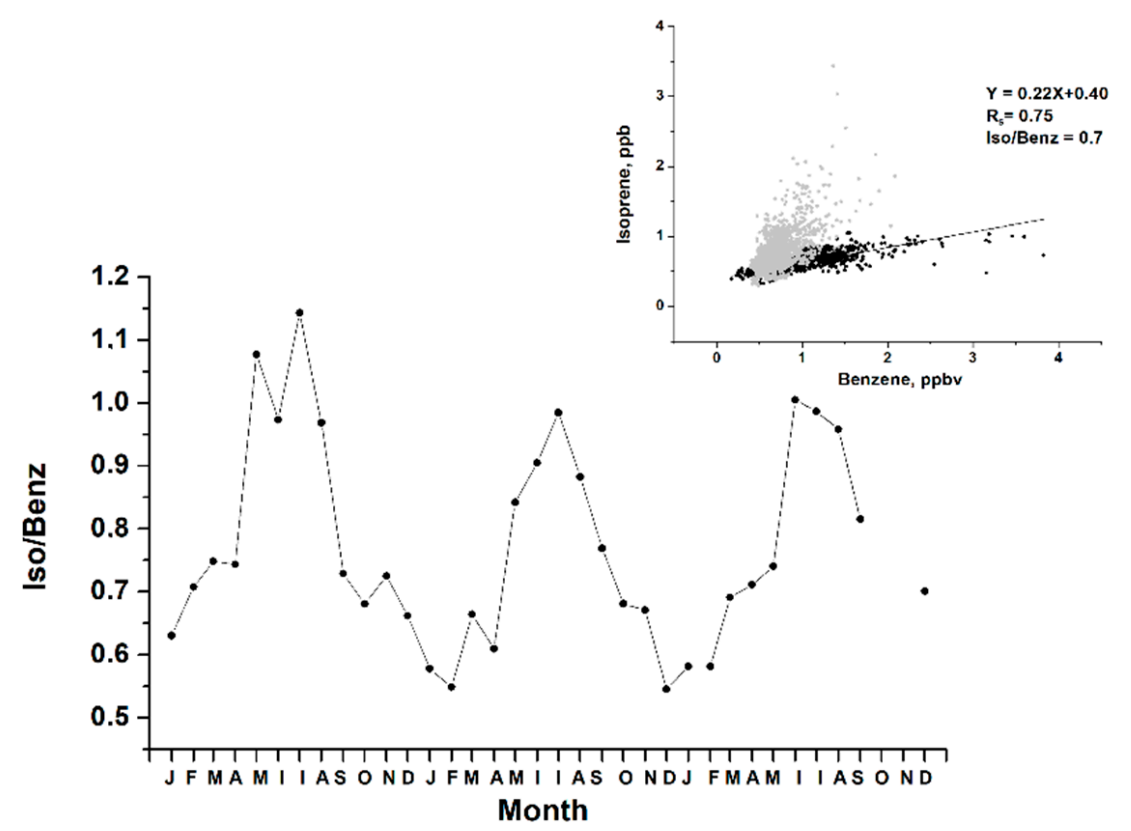

Figure 6. Monthly mean isoprene/benzene ratio from 2011 to 2013 and isoprene versus benzene (black circles: winter nighttime values; white circles: summer daytime values).

\subsection{Ozone Generation in Moscow}

Although mean daytime summer $\mathrm{O}_{3}$ concentration at the MSU-IAP was $\sim 30 \mathrm{ppbv}$ (Figure 7), about $5 \%$ of the observed hourly mean ozone mixing ratios exceeded $80 \mathrm{ppbv}$, marking severe pollution events in Moscow under favorable weather conditions.
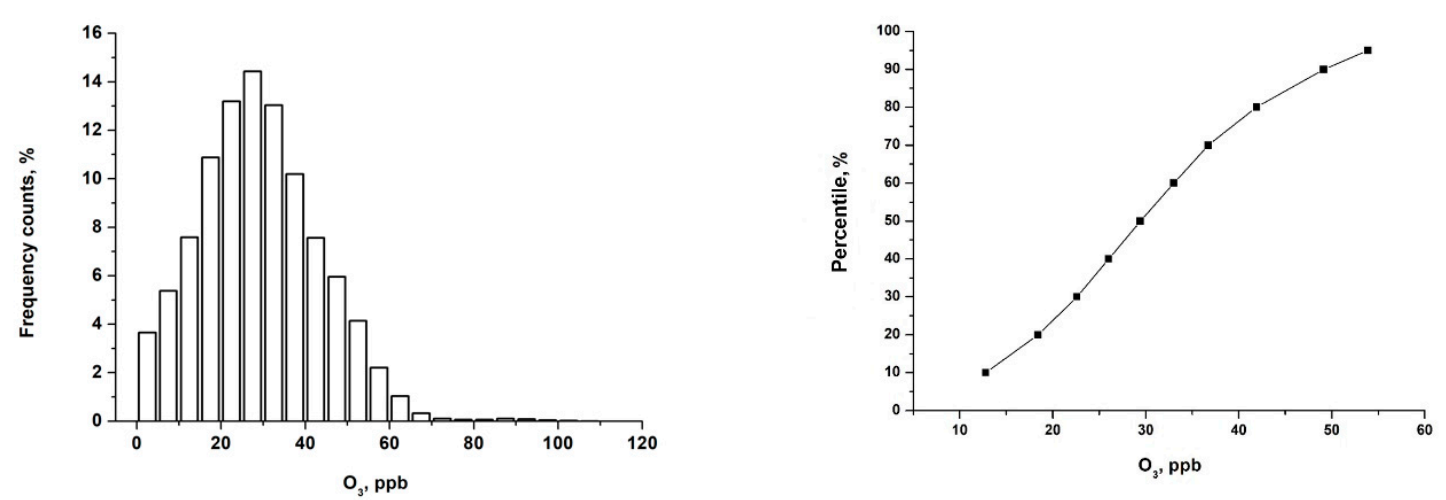

Figure 7. Frequency distribution and percentiles of $\mathrm{O}_{3}$ daytime (10 a.m.-6 p.m. LT) values during the summers of 2011-2013.

According to Figure 8, ground-level $\mathrm{O}_{3}$ mixing ratios decreased with increasing $\mathrm{NOx}$, which is typical for VOC-sensitive urban conditions $[5,6]$. Since the ozone photochemical production rate depends strongly on temperature (Figure $8 b$ ), the highest $\mathrm{O}_{3}$ concentrations were observed at air temperatures $>25^{\circ} \mathrm{C}$ under low-NOx conditions (Figure 8a). 

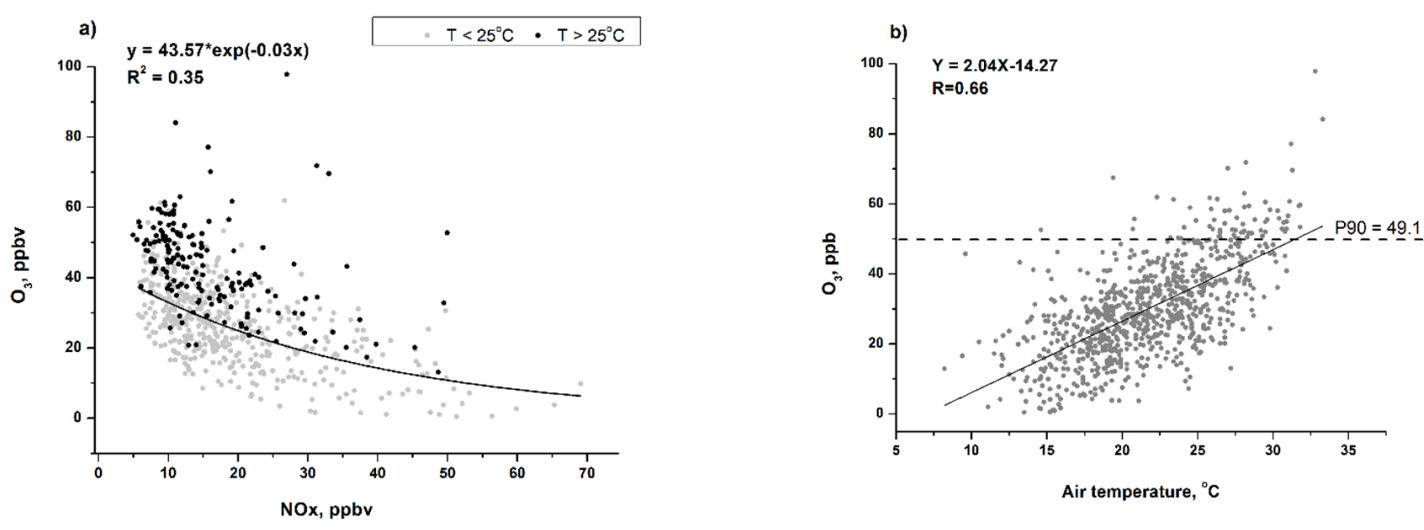

Figure 8. $\mathrm{O}_{3}-\mathrm{NOx}$ daytime dependence (a) and $\mathrm{O}_{3}$ versus air temperature (b) from summer daytime (10 a.m.-6 p.m. LT) measurements ( $\mathrm{R}^{2}$ : determination coefficient; R: Pearson's correlation coefficient).

According to the authors of [10], efficiency of ozone photochemical production depends on the relationship between VOCs and NOx, with an increase in the VOCs/NOx causing an increase in $\mathrm{O}_{3}$ production per $\mathrm{NO}_{x}$ molecule and, consequently, to an increase in $\mathrm{O}_{3}$ ground level concentration. Such behavior is clearly evidenced from our data (Figure 9), showing an ozone production efficiency value ranging from 1 to $6 \mathrm{ppb}_{3}$ per mol NOx based on all summertime measurements.

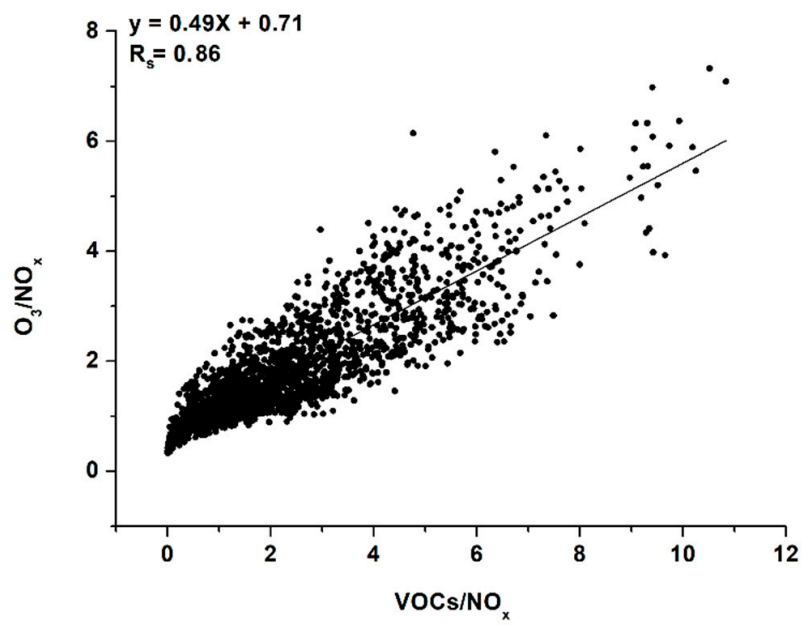

Figure 9. Ozone production per molecule of NOx at different VOC/NOx ratios from summer daytime measurements at the MSU-IAP from 2011 to 2013 ( $\mathrm{R}_{\mathrm{s}}$ : Spearman's correlation coefficient).

\subsection{High $\mathrm{O}_{3}$ Episodes in Moscow}

In summer 2011, two high $\mathrm{O}_{3}$ concentration episodes at the MSU-IAP site were observed, these were from the 27 July ( $3-5$ p.m. LT) and 28 July ( $2-5$ p.m. LT) pollution events. In these events, hourly $\mathrm{O}_{3}$ mixing ratios exceeded $80 \mathrm{ppbv}$, which is well above the short-time MAC value (Figure 10).

Both episodes were observed in the period of hot weather (daytime air temperature $>30^{\circ} \mathrm{C}$ ). During the first episode (27.07), the daytime $\mathrm{O}_{3}$ mixing ratio increased stably and peaked at $4-5$ p.m. LT whereas the observed non-methane hydrocarbons (NMHC) and NOx mixing ratios increased along with $\mathrm{O}_{3}$ until 4 p.m. LT with a subsequent decrease throughout late afternoon. During the second episode (28.07), a simultaneous increase in $\mathrm{O}_{3}$ with a decrease in NMHC and NOx, changed by some outliers, in the concentration graphs of all compounds was observed (Figure 10, right graph) from 3:30 to 5 p.m. LT. 


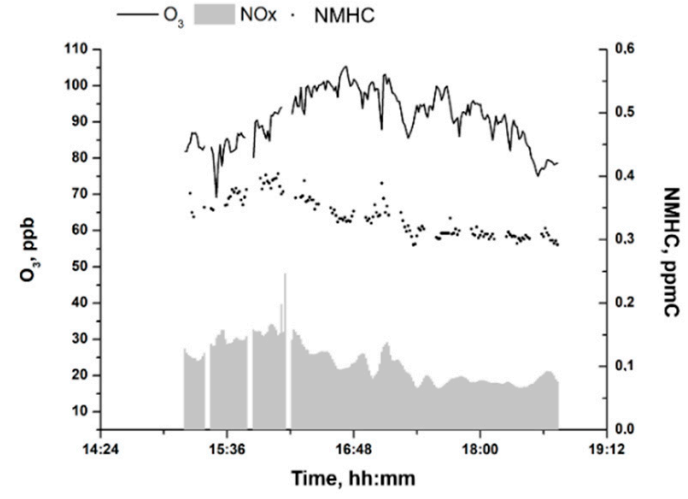

(a)

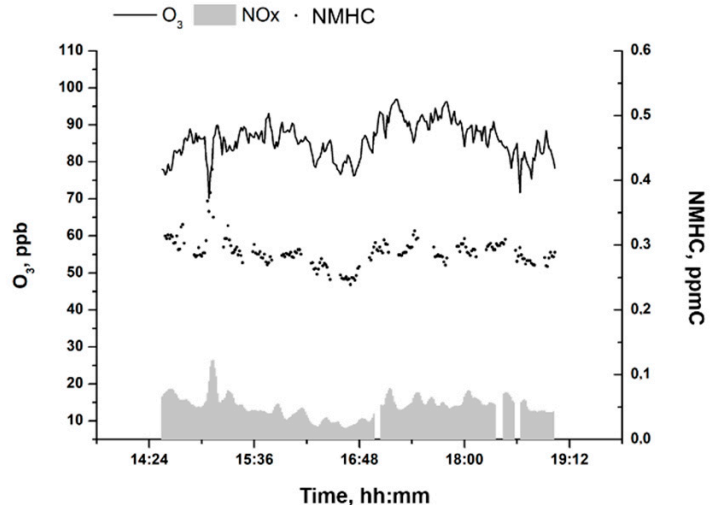

(b)

Figure 10. $\mathrm{High}_{3}$ episodes in Moscow in July 2011 ((a): 27 July, (b): 28 July) from 1-min measurements at the MSU-IAP site.

According to the meteorological data (Figure 11), in July 2011 there was hot and dry weather because of strong anticyclonic conditions. From 27 to $28 \mathrm{July}$, the anticyclone decayed, which was accompanied by the respective drop in atmospheric pressure. In the evening (6-9 p.m. LT), thunderstorms with heavy rain (about $14 \mathrm{~mm}$ of precipitations) and squall winds were observed, accompanied by a change in wind direction from west to east.

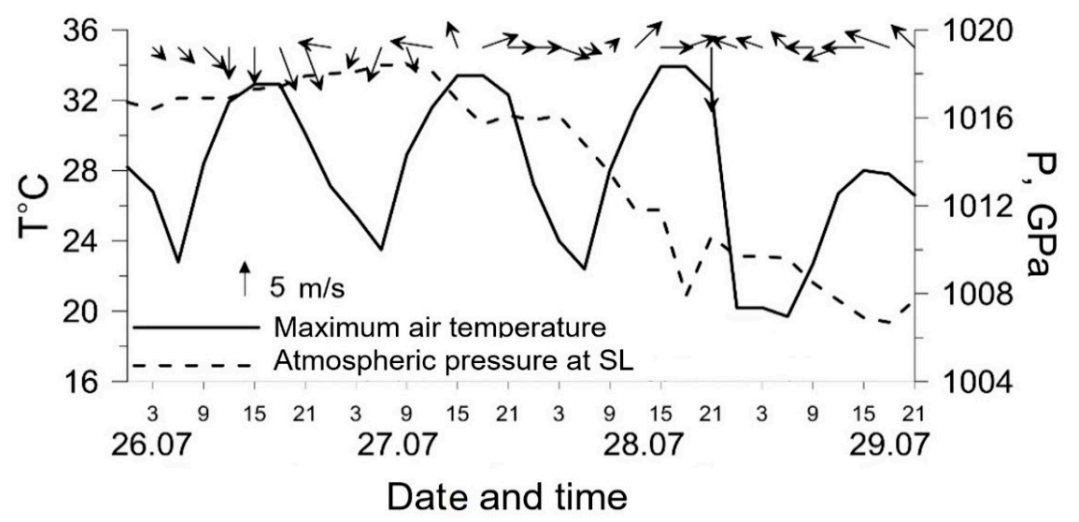

Figure 11. Maximum air temperature, atmospheric pressure at SL (sea level), and speed and wind direction at the MSU-IAP site from 26 to 27 July 2011.

The observed drop in the concentrations of the species at 28 July.2011 is assumed to be connected with the change in the weather conditions and ventilation of the boundary layer through the passage of the front system.

Some studies reported that daytime NMHC/NOx ratios lower than 10 are associated to VOC-sensitive ozone production regimes whereas daytime NMHC/NOx ratios greater than 20 correspond to NOx-sensitive ozone photochemistry [10,12]. Figure 12 shows that during the first high ozone episode, the NMHC/NOx ratio was in the range of 10-20, which points to photochemical ozone production. During the second episode, $\mathrm{O}_{3}$ was produced mainly in NOx-sensitive ( in $80 \%$ of cases) and transitional ( in $20 \%$ of cases) regimes. 

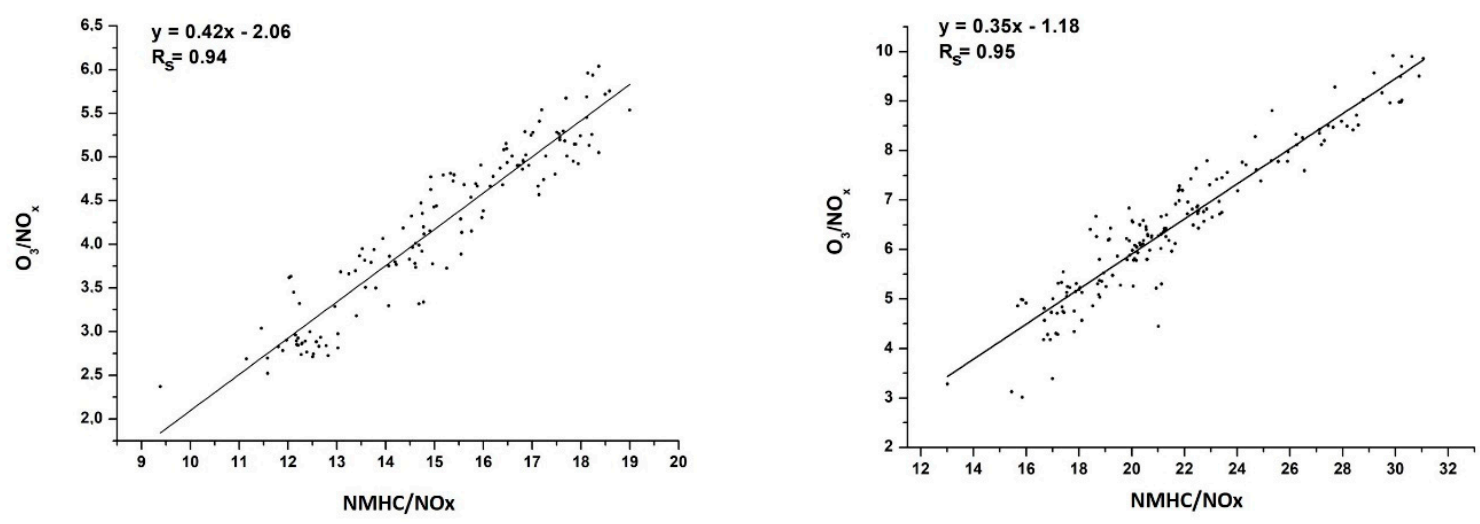

Figure 12. Ozone production per molecule of NOx with different photochemical regimes during the episodes of elevated ozone ( $R_{s}$ : Spearman's correlation coefficient).

There was no significant increase in the concentrations of VOCs measured on 27 and 28 July 2011 compared to that of other days of the month, except for two compounds: acetone and acetic acid (Figure 13). During the high ozone episodes, acetone, acetic acid, and isoprene concentrations exceeded their averages in July 2011 by 5.0, 4.6, and 0.3 ppbv, respectively. Acetone and acetic acid can be both biogenic and anthropogenic. This is confirmed by the high Spearman's correlation of these compounds with biogenic isoprene $\left(\mathrm{R}_{\mathrm{s}}=0.7-0.8\right)$, 2-methyl-3-buten-2-ol $(\mathrm{MBO})\left(\mathrm{R}_{\mathrm{s}}=0.8-0.9\right)$, and anthropogenic benzene $\left(R_{s}=0.5-0.6\right)$ according to our data.

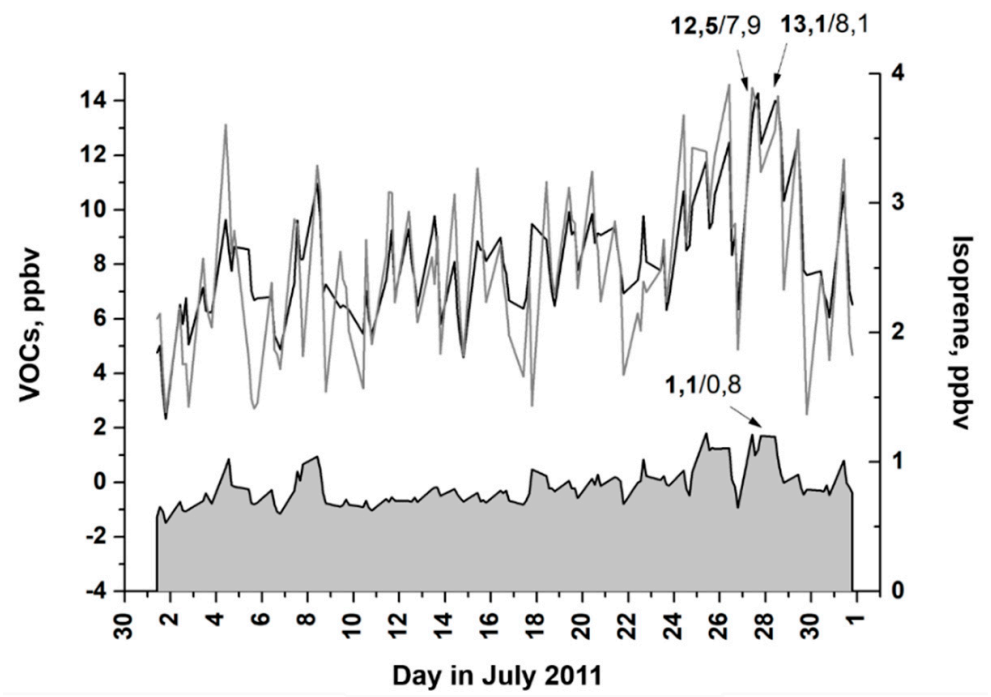

Figure 13. Acetone, acetic acid, and isoprene on July 27 and 28, 2011. The ratios of the daily mean and monthly mean values are near the arrows.

\subsection{VOCs Impact on $\mathrm{O}_{3}$ Generation in Moscow}

To estimate the impact of the measured VOCs on ground-level ozone production in Moscow, we employed the widely used quantity, ozone-forming potential (OFP) [49]:

$$
\mathrm{OFP}\left[\mu \mathrm{g} / \mathrm{m}^{3}\right]=\mathrm{C}_{\mathrm{VOC}} \times \mathrm{MIR}_{\mathrm{VOC}},
$$

where $C_{V O C}$ is a VOC concentration having the dimension of $\mu \mathrm{g} / \mathrm{m}^{3}$ and $\mathrm{MIR}_{\mathrm{VOC}}$ is a maximum incremental reactivity, a dimensionless quantity defined as grams of $\mathrm{O}_{3}$ produced per gram of the VOC [50]. The method allows for estimating the maximum ozone concentration produced from the chemical destruction of the given VOC based on predefined MIR $\mathrm{VOC}$ values. 
For all the measured VOCs in Moscow during the summers of 2011-2013, the OFP values did not exceed $115 \mu \mathrm{g} / \mathrm{m}^{3}$ for $90 \%$ of the measurement time (Figure 14), with the highest OFP values observed during the summer of 2011 (mean $67.3 \mu \mathrm{g} / \mathrm{m}^{3}$, 90-th percentile $103 \mu \mathrm{g} / \mathrm{m}^{3}$ ). Acetaldehyde, 1.3-butadiene, and isoprene were found to play the leading roles in $\mathrm{O}_{3}$ generation, whereas benzene, styrene, phenol, and monoterpenes made a minor contribution to $\mathrm{O}_{3}$ formation in the city (Tables 3 and 4$)$.

During the high July 2011 ozone events, the 90th percentile of OFPs for the total observed VOCs reached $110-136 \mu \mathrm{g} / \mathrm{m}^{3}$ (55-68 ppbv), with acetaldehyde $\left(42-60 \mu \mathrm{g} / \mathrm{m}^{3}\right.$ in $90 \%$ of cases) and 1.3-butadien $\left(16-19 \mu \mathrm{g} / \mathrm{m}^{3}\right.$ in $90 \%$ of cases) making the highest contribution to ozone generation. At the same time, the estimated inputs of acetone, acetic acid, and isoprene, which increased during the high $\mathrm{O}_{3}$ episodes (Figure 13), to ozone production were about 2 times less than that of acetaldehyde and 1.3-butadien. The highest $\mathrm{O}_{3}$ production was found during the first episode on $27 \mathrm{July}$, when the anticyclonic meteorological conditions were not yet changed, as those changes took place during the second episode.

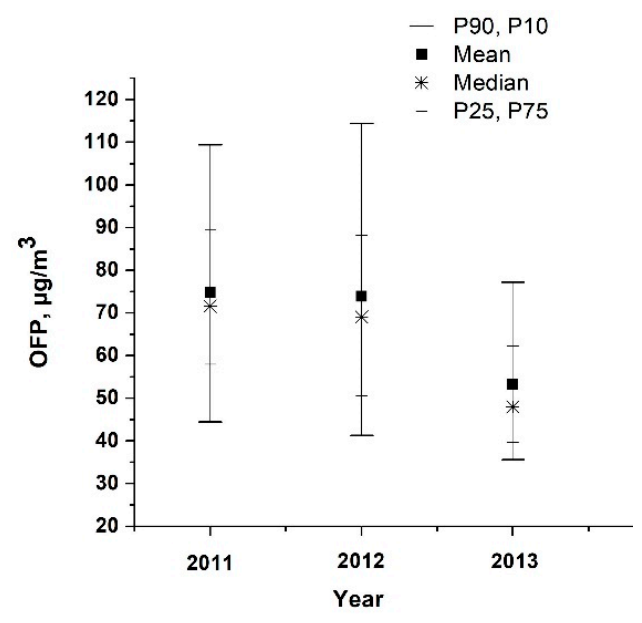

Figure 14. Ozone formation potentials in Moscow (summers of 2011-2013).

Table 3. Daytime ozone-forming potentials (OFPs) (in $\mu \mathrm{g} / \mathrm{m}^{3}$ ) for VOCs measured at the MSU-IAP site during the summers of 2011-2013 (from 1-h VOCs data).

\begin{tabular}{llllll}
\hline VOC & N Total & Mean & Standard Deviation & P10 & P90 \\
\hline Acetaldehyde & 2416 & 20.39 & 14.71 & 4.82 & 39.84 \\
Ethanol & 2422 & 4.74 & 3.12 & 1.65 & 9.89 \\
1.3-Butadiene & 2424 & 13.86 & 9.73 & 6.74 & 28.87 \\
Acetone & 2424 & 1.45 & 0.96 & 0.23 & 2.71 \\
Acetic acid & 2418 & 2.91 & 1.69 & 1.04 & 5.33 \\
Isoprene & 2424 & 9.58 & 12.06 & 3.53 & 26.20 \\
MVK + MACR & 2424 & 3.57 & 1.16 & 2.53 & 5.14 \\
Benzene & 2424 & 0.28 & 0.08 & 0.20 & 0.36 \\
MBO & 2424 & 1.88 & 0.49 & 1.44 & 2.50 \\
Toluene & 2424 & 1.86 & 0.80 & 1.22 & 2.73 \\
Phenol & 2424 & 0.87 & 0.39 & 0.62 & 1.22 \\
Styrene & 2424 & 0.43 & 0.07 & 0.36 & 0.51 \\
C8-aromatics & 2424 & 2.71 & 1.17 & 1.77 & 4.03 \\
C9-aromatics & 2424 & 2.24 & 0.84 & 1.50 & 3.02 \\
Terpenes & 2424 & 0.78 & 0.25 & 0.52 & 1.03 \\
Total VOCs & 2424 & 67.27 & 27.04 & 38.13 & 102.90 \\
\hline
\end{tabular}


Table 4. OFPs (in $\mu \mathrm{g} / \mathrm{m}^{3}$ ) for the high ozone episodes on July 27 and 28, 2011 based on 1-h VOCs data.

\begin{tabular}{ccccccccccc}
\hline \multirow{2}{*}{ VOC } & \multicolumn{2}{c}{ N Total } & \multicolumn{2}{c}{ Mean } & \multicolumn{2}{c}{ Standard Deviation } & \multicolumn{2}{c}{ P10 } & \multicolumn{2}{c}{ P90 } \\
\cline { 2 - 12 } & $\mathbf{1}$ & $\mathbf{2}$ & $\mathbf{1}$ & $\mathbf{2}$ & $\mathbf{1}$ & $\mathbf{2}$ & $\mathbf{1}$ & $\mathbf{2}$ & $\mathbf{1}$ & $\mathbf{2}$ \\
\hline Acetaldehyde & 207 & 264 & 49.92 & 33.08 & 8.76 & 7.04 & 39.54 & 24.6 & 60.29 & 42.06 \\
Ethanol & 207 & 264 & 14.43 & 13.39 & 1.16 & 1.45 & 12.88 & 11.35 & 15.97 & 15.07 \\
1.3-Butadiene & 207 & 264 & 15.73 & 12.92 & 2.15 & 2.11 & 13.08 & 10.39 & 18.60 & 15.47 \\
Acetone & 204 & 264 & 4.23 & 3.87 & 0.40 & 0.46 & 3.71 & 3.38 & 4.78 & 4.45 \\
Acetic acid & 182 & 263 & 7.27 & 6.78 & 0.95 & 0.90 & 6.09 & 5.67 & 8.59 & 7.98 \\
Isoprene & 207 & 264 & 7.98 & 6.93 & 1.64 & 1.57 & 5.95 & 4.85 & 10.20 & 8.85 \\
MVK+ MACR & 207 & 264 & 7.76 & 6.03 & 1.39 & 1.02 & 5.90 & 4.73 & 9.46 & 7.42 \\
Benzene & 207 & 264 & 0.42 & 0.31 & 0.06 & 0.06 & 0.35 & 0.23 & 0.51 & 0.39 \\
MBO & 207 & 264 & 3.25 & 2.96 & 0.51 & 0.53 & 2.66 & 2.33 & 3.95 & 3.67 \\
Toluene & 207 & 264 & 3.03 & 2.09 & 0.59 & 0.45 & 2.30 & 1.55 & 3.91 & 2.66 \\
Phenol & 207 & 264 & 0.81 & 0.91 & 0.18 & 0.18 & 0.57 & 0.67 & 1.06 & 1.15 \\
Styrene & 207 & 264 & 0.37 & 0.43 & 0.09 & 0.08 & 0.25 & 0.32 & 0.48 & 0.54 \\
C8-aromatics & 207 & 264 & 3.57 & 3.01 & 0.94 & 0.65 & 2.52 & 2.20 & 4.85 & 3.79 \\
C9-aromatics & 207 & 264 & 2.12 & 2.05 & 0.59 & 0.61 & 1.33 & 1.29 & 2.97 & 2.88 \\
Terpenes & 207 & 264 & 0.76 & 0.71 & 0.33 & 0.32 & 0.30 & 0.32 & 1.19 & 1.13 \\
Total VOCs & 207 & 264 & 121.70 & 95.50 & 12.22 & 11.27 & 105.86 & 81.3 & 136.38 & 110.36 \\
\hline
\end{tabular}

Thus, the total contribution of all the measured VOCs to daytime ozone levels in Moscow was found to be significant in hot and calm weather conditions. $\mathrm{O}_{3}$ production from VOCs was $31-67 \mu \mathrm{g} / \mathrm{m}^{3}$ on average and in $10 \%$ of cases exceeded $100 \mu \mathrm{g} / \mathrm{m}^{3}$. Anticyclonic conditions with high air temperature (above $30^{\circ} \mathrm{C}$ ), low cloud cover, and low wind speeds led to active ozone generation in the presence of local pollution sources and resulted in near-surface day-time ozone mixing ratios exceeding hazardous levels (OFPs from total VOCs was about $100-122 \mu \mathrm{g} / \mathrm{m}^{3}$ on average and were higher than $136 \mathrm{in} 10 \%$ of calculations).

\section{Conclusions}

The detailed analysis of ground-level $\mathrm{O}_{3}$ and its precursors measured at the MSU-IAP site located in the southwestern part of Moscow (about $8 \mathrm{~km}$ away from the city center) showed the highest $\mathrm{O}_{3}$ to be in the daytime warm periods of the observation period. $\mathrm{The}_{3}$ mixing ratio increased monotonically from early morning, reaching its maximum value of $34 \mathrm{ppbv}$ (sample mean) at $\sim 4 \mathrm{p} . \mathrm{m}$. LT. However, anticyclonic meteorological conditions with high air temperatures (above $25^{\circ} \mathrm{C}$ ) and low wind speeds ( $2-3 \mathrm{~m} / \mathrm{s}$ ) contributed to $\mathrm{O}_{3}$ reaching a hazardous level (up to $105 \mathrm{ppbv}$ or $210 \mu \mathrm{g} / \mathrm{m}^{3}$ ) in the city.

Diurnal variations of anthropogenic $\mathrm{O}_{3}$ precursors, $\mathrm{NOx}, \mathrm{CO}$, and benzene, were opposite to that of ozone, showing a stable decrease from their morning peak values at 8 a.m. to late afternoon minimums at 5-6 p.m. LT. The observed diurnal variability of the above species can be explained by changes in vertical mixing intensity in the course of the day. Additionally, chemical distraction of the primary emitted VOCs, with the benzene as an example, could contribute to their daytime decrease, accompanied by significant accumulation of $\mathrm{O}_{3}$ and other secondary pollutants. The maximum $\mathrm{O}_{3}$ production rate was observed during the late morning hours (10-12 a.m. LT) which coincided markedly with diurnal peaks in a number of the most abundant secondary VOCs (acetaldehyde, acetone, and acetic acid). The origin of the observed late morning maximum of the above species could be attributed to both photochemical oxidation of primary emitted VOCs after sunrise and entrainment of partially oxidized products from the upper layers under development of the convective boundary layer. The high positive relationships of acetaldehyde, ethanol, acetone, and acetic acid with each other $\left(R_{s}=0.6-0.9\right)$ and with the products of isoprene oxidation, MVK and MACR, $\left(R_{s}=0.7-0.8\right)$ and no correlation with $\mathrm{CO}$ and NOx confirmed the significant role of photochemistry in the production of these VOCs in the city along with their primary sources. The positive correlation of daytime $\mathrm{O}_{3}$ $\left(\mathrm{R}_{\mathrm{s}}=0.5\right)$ with secondary VOCs affirmed an important role of photochemical $\mathrm{O}_{3}$ production in Moscow during the summers of 2011-2013. 
The toluene to benzene ratio (T/B), which can serve as an indicator of vehicle pollution as well as air chemical aging, suggested that the dominant anthropogenic VOCs source in Moscow was local vehicle emissions. The non-linear $\mathrm{O}_{3}-\mathrm{NOx}$ dependence showed a decrease in ground-level $\mathrm{O}_{3}$ with am increase in NOx, which is typical for the VOC-sensitive photochemical regime of $\mathrm{O}_{3}$ formation in Moscow. Increase in the VOCs/NOx ratio caused an increase in $\mathrm{O}_{3}$ production of the NOx molecule and, consequently, to an increase in ground-level $\mathrm{O}_{3}$ concentration. The $\mathrm{NMHC} / \mathrm{NOx}$ ratio calculated for the elevated ozone episodes in July 2011 showed that $\mathrm{O}_{3}$ was mainly generated in the conditions of transitional and NOx-sensitive photochemical regimes.

The concentrations of the biogenic VOCs isoprene and monoterpenes were $0.73 \mathrm{ppbv}$ and 0.53 ppbv, respectively, on average. Their diurnal variations were poorly distinguished, which may have been due to the mainly southwest and west winds blowing from the roads and limited vegetation area. The high positive relationship of isoprene $\left(R_{s}=0.7\right)$ with the vehicle exhaust tracer benzene in the summer daytime hours pointed to the impact of anthropogenic isoprene on the data. The calculated nighttime winter isoprene/benzene ratio showed that about $5 \%$ of the daytime summer isoprene in Moscow was anthropogenic.

For all the measured VOCs in Moscow from 2011 to 2013, OFP values did not exceed $115 \mu \mathrm{g} / \mathrm{m}^{3}$ in $90 \%$ of the whole observation period. The highest OFPs were found in 2011 and $2012\left(67.3 \mu \mathrm{g} / \mathrm{m}^{3}\right.$ on average and did not exceed $103 \mu \mathrm{g} / \mathrm{m}^{3}$ in $90 \%$ of cases). The lowest $\mathrm{O}_{3}$ formation was found in 2013 $\left(31.3 \mu \mathrm{g} / \mathrm{m}^{3}\right.$ on average and did not exceed $44.3 \mu \mathrm{g} / \mathrm{m}^{3}$ in $90 \%$ of cases). Acetaldehyde, 1.3-butadiene, and isoprene played the leading roles in $\mathrm{O}_{3}$ generation $\left(9.6-20.4 \mu \mathrm{g} / \mathrm{m}^{3}\right.$ in average). Benzene, styrene, phenol, and monoterpenes made less of a contribution to $\mathrm{O}_{3}$ formation in the city $\left(0.3-0.9 \mu \mathrm{g} / \mathrm{m}^{3}\right.$ in average). Anticyclonic conditions catalyzed active generation of ground-level $\mathrm{O}_{3}$ in polluted urban air (OFPs from total VOCs was about $100-122 \mu \mathrm{g} / \mathrm{m}^{3}$ on average and were higher than $136 \mu \mathrm{g} / \mathrm{m}^{3}$ in $10 \%$ of calculations).

Supplementary Materials: The following are available online at http://www.mdpi.com/2073-4433/11/11/1262/s1. Figure S1: Frequency distribution of some atmospheric compounds in Moscow (summers of 2011-2013).

Author Contributions: All authors contributed to the original draft preparation of the manuscript; I.B.B., V.A.B. and N.F.E. conceived and designed the experiments; E.V.B., K.B.M. and N.V.P. contributed to the data analysis; K.B.M. and A.I.S. provided project administration and revised the whole manuscript. All authors have read and agreed to the published version of the manuscript.

Funding: This work was funded by the Russian Foundation for Basic Research (grants \# 18-35-20031 (VOCs impact on $\mathrm{O}_{3}$ generation in cities) and \#19-05-50088 (transformation of polluting gases in Moscow)).

Acknowledgments: The authors acknowledge the colloquies with the MSU meteorological observatory for provision of meteorological data.

Conflicts of Interest: The authors declare no conflict of interest.

\section{References}

1. Lefohn, A.S.; Malley, C.S.; Smith, L.; Wells, B.; Hazucha, M.; Simon, H.; Naik, V.; Mills, G.; Schultz, M.G.; Paoletti, E.; et al. Tropospheric ozone assessment report: Global ozone metrics for climate change, human health, and crop/ecosystem research. Elem. Sci. Anth. 2018, 6, 1-28. [CrossRef]

2. Manisalidis, I.; Stavropoulou, E.; Stavropoulos, A.; Bezirtzoglou, E. Environmental and Health Impacts of Air Pollution: A Review. Front. Public Health 2020, 8, 14. [CrossRef] [PubMed]

3. Seinfeld, J.H. Chemistry of Ozone in The Urban and Regional Atmosphere. In Conical Intersections; World Scientific Publishing Co Pte Ltd.: Singapore, 1995; Volume 3, pp. 34-57.

4. Thielmann, A.; Grüebler, F.C.; Prévôt, A.S.H.; Staehelin, J. Empirical ozone isopleths as a tool to identify ozone production regimes. Geophys. Res. Lett. 2001, 28, 2369-2372. [CrossRef]

5. Bowman, F.M.; Seinfeld, J.H. Ozone productivity of atmospheric organics. J. Geophys. Res. Space Phys. 1994, 99, 5309-5324. [CrossRef]

6. Mazzuca, G.M.; Ren, X.; Loughner, C.P.; Estes, M.; Crawford, J.H.; Pickering, K.E.; Weinheimer, A.J.; Dickerson, R.R. Ozone production and its sensitivity to NOx and VOCs: Results from the DISCOVER-AQ field experiment, Houston 2013. Atmos. Chem. Phys. Discuss. 2016, 16, 14463-14474. [CrossRef] 
7. Sharma, A.; Sharma, S.K.; Rohtash; Mandal, T.K. Influence of ozone precursors and particulate matter on the variation of surface ozone at an urban site of Delhi, India. Sustain. Environ. Res. 2016, 26, 76-83. [CrossRef]

8. Chang, C.-Y.; Faust, E.; Hou, X.; Lee, P.; Kim, H.C.; Hedquist, B.C.; Liao, K.-J. Investigating ambient ozone formation regimes in neighboring cities of shale plays in the Northeast United States using photochemical modeling and satellite retrievals. Atmos. Environ. 2016, 142, 152-170. [CrossRef]

9. Karl, T.; Graus, M.; Striednig, M.; Lamprecht, C.; Hammerle, A.; Wohlfahrt, G.; Held, A.; Von Der Heyden, L.; Deventer, M.J.; Krismer, A.; et al. Urban eddy covariance measurements reveal significant missing NOx emissions in Central Europe. Sci. Rep. 2017, 7, 1-9. [CrossRef]

10. Sillman, S. The relation between ozone, NOx and hydrocarbons in urban and polluted rural environments. Atmos. Environ. 1999, 33, 1821-1845. [CrossRef]

11. Goldberg, D.L.; Vinciguerra, T.P.; Anderson, D.C.; Hembeck, L.; Canty, T.P.; Ehrman, S.H.; Martins, D.K.; Stauffer, R.M.; Thompson, A.M.; Salawitch, R.J.; et al. CAMx Ozone Source Attribution in the Eastern United States using Guidance from Observations during DISCOVER-AQ Maryland. Geophys. Res. Lett. 2016, 43, 2249-2258. [CrossRef]

12. Jin, X.; Fiore, A.M.; Murray, L.T.; Valin, L.C.; Lamsal, L.N.; Duncan, B.; Boersma, K.F.; De Smedt, I.; Abad, G.G.; Chance, K.; et al. Evaluating a Space-Based Indicator of Surface Ozone-NOx-VOC Sensitivity Over Midlatitude Source Regions and Application to Decadal Trends. J. Geophys. Res. Atmos. 2017, 122, 10-439. [CrossRef] [PubMed]

13. Duan, J.; Tan, J.; Yang, L.; Wu, S.; Hao, J. Concentration, sources and ozone formation potential of volatile organic compounds (VOCs) during ozone episode in Beijing. Atmos. Res. 2008, 88, 25-35. [CrossRef]

14. Guo, H.; Lyu, X.; Cheng, H.; Ling, Z.; Guo, H. Overview on the spatial-temporal characteristics of the ozone formation regime in China. Environ. Sci. Process. Impacts 2019, 21, 916-929. [CrossRef]

15. Tan, Z.; Lu, K.; Jiang, M.; Su, R.; Dong, H.; Zeng, L.; Xie, S.; Tan, Q.; Zhang, Y. Exploring ozone pollution in Chengdu, southwestern China: A case study from radical chemistry to O3-VOC-NOx sensitivity. Sci. Total. Environ. 2018, 636, 775-786. [CrossRef]

16. Thielmann, A.; Prévôt, A.S.H.; Staehelin, J. Sensitivity of ozone production derived from field measurements in the Italian Po basin. J. Geophys. Res. Space Phys. 2002, 107, 8194. [CrossRef]

17. Ren, X.; Van Duin, D.; Cazorla, M.; Chen, S.; Mao, J.; Zhang, L.; Brune, W.H.; Flynn, J.; Grossberg, N.; Lefer, B.L.; et al. Atmospheric oxidation chemistry and ozone production: Results from SHARP 2009 in Houston, Texas. J. Geophys. Res. Atmos. 2013, 118, 5770-5780. [CrossRef]

18. Xue, L.K.; Wang, T.; Gao, J.; Ding, A.; Zhou, X.H.; Blake, D.R.; Wang, X.F.; Saunders, S.M.; Fan, S.J.; Zuo, H.C.; et al. Ozone production in four major cities of China: Sensitivity to ozone precursors and heterogeneous processes. Atmos. Chem. Phys. Discuss. 2013, 13, 27243-27285. [CrossRef]

19. Elansky, N.F. Impurities in the atmosphere of continental Russia. Priroda 2002, 2, 32-43, [In Russian].

20. Elansky, N.; Lokoshchenko, M.A.; Trifanova, A.V.; Belikov, I.B.; Ckorokhod, A.I. On Contents of Trace Gases in the Atmospheric Surface Layer over Moscow. Izv. Atmos. Ocean. Phys. 2015, 51, 39-51. [CrossRef]

21. Elanskii, N.F.; Belikov, I.B.; Golitsyn, G.S.; Grisenko, A.M.; Lavrova, O.V.; Pankratova, N.V.; Safronov, A.N.; Skorokhod, A.I.; Shumskii, R.A. Observations of the atmosphere composition in the Moscow megapolis from a mobile laboratory. Dokl. Earth Sci. 2010, 432, 649-655. [CrossRef]

22. Gorchakov, G.I.; Semutnikova, E.G.; Isakov, A.A.; Kopeikin, V.M.; Karpov, A.V.; Kurbatov, G.A.; Ponomareva, T.Y.; Sokolov, A.V. The Moscow smoke haze of 2010: Extreme aerosol and gaseous air pollution of in the Moscow region. Atmos. Ocean. Opt. 2011, 24, 6, 452-458.

23. Yurganov, L.N.; Rakitin, V.; Dzhola, A.; August, T.; Fokeeva, E.; George, M.; Gorchakov, G.; Grechko, E.; Hannon, S.; Karpov, A.; et al. Satellite- and ground-based CO total column observations over 2010 Russian fires: Accuracy of top-down estimates based on thermal IR satellite data. Atmos. Chem. Phys. Discuss. 2011, 11, 7925-7942. [CrossRef]

24. Lokoshchenko, M.A.; Elansky, N.F.; Trifanova, A.V.; Belikov, I.B.; Skorokhod, A.I. Limiting levels of air pollution in Moscow. Vestn. Mosk. Univ. Geogr. 2016, 5, 29-39.

25. Lokoshchenko, M.A.; Elanskii, N.F.; Malyashova, V.P.; Trifanova, A.V. Dynamics of the surface content of sulfur dioxide in Moscow. Atmos. Ocean. Opt. 2015, 21, 384-391.

26. Causes and factors of positive anomalies of surface ozone in the Moscow region and the south-eastern coast of the Crimea. Atmos. Ocean. Opt. 2016, 29, 493-502. [CrossRef] 
27. GOST 17.2.3.01-86. Environmental Protection. Atmospheric Air. Residential Air Quality Control Regulations; USSR State Committee of Standards: Moscow, Russia, 1986; (In Russian)

28. Elansky, N.F.; Lokoshchenko, M.A.; Belikov, I.B.; Skorokhod, A.I.; Shumskii, R.A. Variability of trace gases in the atmospheric surface layer from observations in the city of Moscow. Izv. Atmos. Ocean. Phys. 2007, 43, 219-231. [CrossRef]

29. Elansky, N.F.; Belikov, I.B.; Berezina, E.V. Atmospheric Composition over Northern Eurasia: The TROICA Experiments; Agrospas: Moscow, Russia, 2009; pp. 73-90.

30. Chubarova, N.Y. UV variability in Moscow according to long-term UV measurements and reconstruction model. Atmos. Chem. Phys. Discuss. 2008, 8, 3025-3031. [CrossRef]

31. Nezval, E.I.; Chubarova, N.E. Long-term variability of UV radiation in the spectral range of 300-380 $\mathrm{nm}$ in Moscow. Russ. Meteorol. Hydrol. 2017, 42, 693-699. [CrossRef]

32. Elansky, N.F.; Shilkin, A.V.; Ponomarev, N.A.; Semutnikova, E.G.; Zakharova, P.V. Weekly patterns and weekend effects of air pollution in the Moscow megacity. Atmos. Environ. 2020, 224, 117303. [CrossRef]

33. Crutzen, P.J.; Elansky, N.F.; Hahn, M.; Golitsyn, G.S.; Brenninkmeijer, C.A.M.; Scharffe, D.H.; Belikov, I.B.; Maiss, M.; Bergamaschi, P.; Röckmann, T.; et al. Trace Gas Measurements Between Moscow and Vladivostok Using the Trans-Siberian Railroad. J. Atmos. Chem. 1998, 29, 179-194. [CrossRef]

34. Monks, P.S. A review of the observations and origins of the spring ozone maximum. Atmos. Environ. 2000, 34, 3545-3561. [CrossRef]

35. Pochanart, P.; Kajii, Y.; Potemkin, V.M.; Khodzher, T.V.; Akimoto, H. Regional background ozone and carbon monoxide variations in remote Siberia/East Asia. J. Geophys. Res. Space Phys. 2003, 108, 4028. [CrossRef]

36. Belikov, I.B.; Belousov, V.A.; Gubanova, D.P.; Skorokhod, A.I. Variations in the Concentrations of Volatile Organic Compounds and Aerosol Particles PM2.5 In the Surface Layer of the Atmosphere of Moscow. In Proceedings of the Fundamental and Applied Aspects of Geology, Geophysics and Geoecology Using Modern Information Technologies, Maykop, Russia, 20-24 May 2019; pp. 80-89, ISBN 978-5-907004-38-2. (In Russian)

37. Lokoshchenko, M.A. Long-Term Sodar Observations in Moscow and a New Approach to Potential Mixing Determination by Radiosonde Data. J. Atmos. Ocean. Technol. 2002, 19, 1151-1162. [CrossRef]

38. Liu, S.C.; Trainer, M.; Fehsenfeld, F.C.; Parrish, D.D.; Illiams, E.J.W.; Fahey, D.W.; Hübler, G.; Murphy, P.C. Ozone production in the rural troposphere and the implications for regional and global ozone distributions. J. Geophys. Res. Space Phys. 1987, 92, 4191-4207. [CrossRef]

39. Tiwari, V.; Hanai, Y.; Masunaga, S. Ambient levels of volatile organic compounds in the vicinity of petrochemical industrial area of Yokohama, Japan. Air Qual. Atmos. Health 2010, 3, 65-75. [CrossRef] [PubMed]

40. Shaw, M.D.; Lee, J.D.; Davison, B.; Vaughan, A.R.; Purvis, R.; Harvey, A.; Lewis, A.C.; Hewitt, C.N. Airborne determination of the temporo-spatial distribution of benzene, toluene, nitrogen oxides and ozone in the boundary layer across Greater London, UK. Atmos. Chem. Phys. Discuss. 2015, 15, 5083-5097. [CrossRef]

41. Carballo-Pat., C.G.; Cerón-Bretón, J.G.; Cerón-Bretón, R.M.; Ramírez-Lara, E.; Aguilar-Ucán, C.A.; Montalvo-Romero, C.; Guevara-Carrió, E.; Córdova-Quiroz, A.V.; Gamboa-Fernández, J.M.; Uc-Chi, M.P. Latest trends in Energy. Environment and Development. In Proceedings of the 7-th International Conference on Environmental and Geological Sciences and Engineering (EG'14), Salerno, Italy, 3-5 June 2014; pp. 132-140.

42. Warneke, C.; van der Veen, C.; Luxembourg, S.; de Gouw, J.A.; Kok, A. Measurements of benzene and toluene in ambient air using proton-transfer-reaction mass spectrometry: Calibration humidity dependence and field intercomparison. Int. J. Mass Spectrom. 2001, 207, 167-182. [CrossRef]

43. Atkinson, R. Atmospheric chemistry of VOCs and NOx. Atmos. Environ. 2000, 34, 2063-2101. [CrossRef]

44. Gelencsér, A.; Siszler, A.K.; Hlavay, J. Toluene-Benzene Concentration Ratio as a Tool for Characterizing the Distance from Vehicular Emission Sources. Environ. Sci. Technol. 1997, 31, 2869-2872. [CrossRef]

45. Wagner, P.; Kuttler, W. Biogenic and anthropogenic isoprene in the near-surface urban atmosphere-A case study in Essen, Germany. Sci. Total Environ. 2014, 475, 104-115. [CrossRef]

46. Wang, J.L.; Chew, C.; Chang, C.Y.; Liao, W.C.; Lung, S.C.C.; Chen, W.N.; Lee, P.J.; Lin, P.H.; Chang, C.C. Biogenic isoprene in subtropical urban settings and implications for air quality. Atmos. Environ. 2013, 79, 369-379. [CrossRef] 
47. Chang, C.-Y.; Wang, J.-L.; Lung, S.-C.; Lee, P.-J.; Chew, C.; Liao, W.-C.; Chen, W.-N.; Ou-Yang, C.-F. Seasonal characteristics of biogenic and anthropogenic isoprene in tropical-subtropical urban environments. Atmos. Environ. 2014, 99, 298-308. [CrossRef]

48. Borbon, A.; Fontaine, H.; Locoge, N.; Veillerot, M.; Galloo, J. Developing receptor-oriented methods for non-methane hydrocarbon characterisation in urban air-Part I: Source identification. Atmos. Environ. 2003, 37, 4051-4064. [CrossRef]

49. Carter, W.P.L. Development of Ozone Reactivity Scales for Volatile Organic Compounds. J. Air Waste Manag. Assoc. 1994, 44, 881-899. [CrossRef]

50. Carter, W.P.L. Development of the SAPRC-07 Chemical Mechanism and Updated Ozone Reactivity Scales, Final report to the California Air Resources Board Contract No. 03-318. California, USA. 27 January 2010. Available online: https://intra.engr.ucr.edu/ \{\}carter/pubs/ (accessed on 20 November 2020).

Publisher's Note: MDPI stays neutral with regard to jurisdictional claims in published maps and institutional affiliations.

(C) 2020 by the authors. Licensee MDPI, Basel, Switzerland. This article is an open access article distributed under the terms and conditions of the Creative Commons Attribution (CC BY) license (http://creativecommons.org/licenses/by/4.0/). 